\title{
Highly Durable Direct Methanol Fuel Cell with Double-Layered Catalyst Cathode
}

\author{
Jing Liu, ${ }^{1}$ Chun-Tao Liu, ${ }^{1,2}$ Lei Zhao, ${ }^{3}$ and Zhen-Bo Wang ${ }^{3}$ \\ ${ }^{1}$ School of Chemistry and Materials Science, Heilongjiang University, Harbin 150080, China \\ ${ }^{2}$ Key Laboratory of Chemical Engineering Process and Technology for High efficiency Conversion, \\ College of Heilongjiang Province, Harbin 150080, China \\ ${ }^{3}$ School of Chemical Engineering and Technology, Harbin Institute of Technology, Harbin 150001, China
}

Correspondence should be addressed to Chun-Tao Liu; liuct@hlju.edu.cn and Zhen-Bo Wang; wangzhb@hit.edu.cn

Received 14 June 2015; Revised 23 June 2015; Accepted 29 June 2015

Academic Editor: Jun Chen

Copyright (C) 2015 Jing Liu et al. This is an open access article distributed under the Creative Commons Attribution License, which permits unrestricted use, distribution, and reproduction in any medium, provided the original work is properly cited.

Polymer electrolyte membrane (PEM) is one of the key components in direct methanol fuel cells. However, the PEM usually gets attacked by reactive oxygen species during the operation period, resulting in the loss of membrane integrity and formation of defects. Herein, a double-layered catalyst cathode electrode consisting of $\mathrm{Pt} / \mathrm{CeO}_{2}-\mathrm{C}$ as inner catalyst and $\mathrm{Pt} / \mathrm{C}$ as outer catalyst is fabricated to extend the lifetime and minimize the performance loss of DMFC. Although the maximum power density of membrane electrode assembly (MEA) with catalyst cathode is slightly lower than that of the traditional one, its durability is significantly improved. No obvious degradation is evident in the MEA with double-layered catalyst cathode within durability testing. These results indicated that $\mathrm{Pt} / \mathrm{CeO}_{2}-\mathrm{C}$ as inner cathode catalyst layer greatly improved the stability of MEA. The significant reason for the improved stability of MEA is the ability of $\mathrm{CeO}_{2}$ to act as free-radical scavengers.

\section{Introduction}

Direct methanol fuel cell (DMFC) is one of polymer electrolyte membrane fuel cell (PEMFC); it is a promising candidate for electric vehicle and portable electronic devices owing to its high efficiency, environmental friendliness, and convenience [1-5]. Despite an early commercialization of the introduction, the high cost and inferior stability have been main obstacles hindering the widespread commercialization of DMFC technology. One of the key causes for high cost is the use of precious metal catalysts for anode and cathode electrodes to get stable and good fuel cell performance [6]. Moreover, the improvement of stability of fuel cell is a crucial factor on cost. A substantial portion of the published work has been focused on enhancing durable and reliable fuel cell lifetime through electrode structure design, PEM modification, the optimization of operation strategies, and the invention of new electrode materials [7-11]. Unfortunately, DMFCs lifetime has still been short of the 5,000 hours, which will be a challenge of DMFC commercialization $[6,12,13]$.
Generally, the voltage degradation of DMFC escalates with the increasing of operation time. One of the main causes of the degradation is the membrane's chemical degradation, which is attributed to reactive oxygen species. Under the condition of transition metal cations, radicals are caused by electrochemical and chemical reactions on DMFC electrode. It can split $\mathrm{H}_{2} \mathrm{O}_{2}$ generated from two electronic processes of oxygen reduction reaction, or direct reaction of hydrogen and oxygen on cathode [13-16]. These conditions lead to the attack of side chain of perfluorinated sulfonic acid ionomers, resulting in the loss of membrane integrity and formation of defects. The membrane is attacked by free-radicals, which shortens the lifetime of fuel cell. Hence, free-radical should be eliminated to enhance the stability of fuel cell.

$\mathrm{CeO}_{2}$ ceramic materials are widely used in various application fields, such as catalyst carrier for fuel cell, solid electrolyte for solid oxide fuel cells, and scavenger for freeradical in biological systems [17]. In addition, they exhibit a renewable nature, especially in the acidic condition [18, 19]. These properties are attributed to +3 and +4 oxidation 


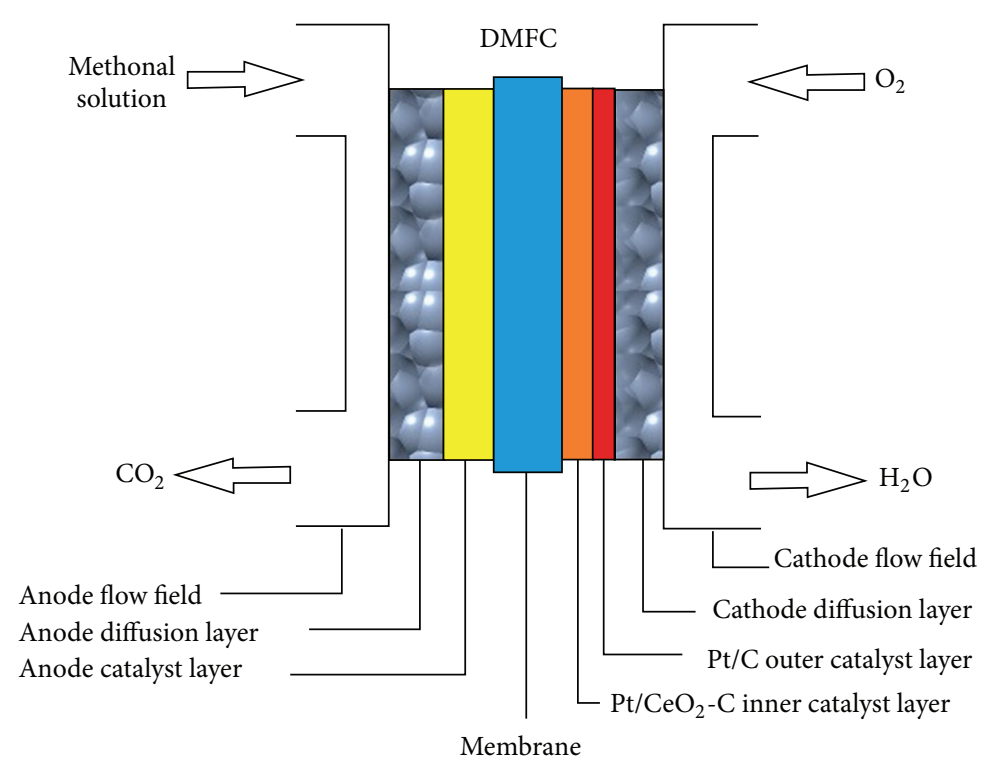

FIgURE 1: The schematic diagram of DMFC.

states of cerium atoms in $\mathrm{CeO}_{2}$ and the consequent presence of the oxygen storage capacity in $\mathrm{CeO}_{2}$ [20-22]. In recent years, Nafion $/ \mathrm{CeO}_{2}$ composite membrane has been prepared to improve the stability of PEM [23-25]. The composite membranes present high durability and a good compatible interface; however, their applications are limited by the sensitivity of temperature and proton conductivity of Nafion membrane [24].

In this work, in order to enhance the stability of DMFC, we design a double-layered catalyst cathode electrode containing $\mathrm{Pt} / \mathrm{CeO}_{2}-\mathrm{C}$ as inner catalyst layer and $\mathrm{Pt} / \mathrm{C}$ as outer catalyst layer. Our design arises from the free-radical scavenger ability of $\mathrm{CeO}_{2}$ in fuel cell without effecting proton conductivity of PEM and the convenient preparation. The experimental results show that the membrane electrode assembly (MEA) with double-layered catalyst cathode possesses high durability in comparison with the conventional one.

\section{Experimental Detail}

2.1. Catalyst Preparation. $\mathrm{CeO}_{2}$ nanoparticles were synthesized through a precipitation method. Briefly, the dilute $\mathrm{NH}_{3} \cdot \mathrm{H}_{2} \mathrm{O}$ solution was dropped into the $\mathrm{Ce}\left(\mathrm{NO}_{3}\right)_{3} \cdot 6 \mathrm{H}_{2} \mathrm{O}$ aqueous solution with magnetic stirring and its $\mathrm{pH}$ value reached 10 at $80^{\circ} \mathrm{C}$. Then, light yellow suspended solution was aged for $4 \mathrm{~h}$. The product was washed for several times with heated deionized water (Millipore, $18.2 \mathrm{M} \Omega \mathrm{cm}$ ) and dried at $80^{\circ} \mathrm{C}$ for $12 \mathrm{~h}$. The power was calcined at $450^{\circ} \mathrm{C}$ for $1 \mathrm{~h}$ under air.

All homemade catalysts were prepared through the microwave-assisted polyol process (MAPP) as reported by our team $[26,27]$, and their the metal loading was $40 \mathrm{wt} . \%$. The $\mathrm{CeO}_{2}$ content of $\mathrm{CeO}_{2}-\mathrm{C}$ was 30 wt. $\%$. In detail, a certain amount of Vulcan XC-72 carbon black (Cabot) was dispersed into $50 \mathrm{~mL}$ mixture of isopropyl alcohol and ethylene glycol
(EG) $(\mathrm{v}: \mathrm{v}=1: 4)$ and under ultrasonic treatment for $30 \mathrm{~min}$ to form uniform suspension. Then, a calculated amount $0.0385 \mathrm{~mol} \mathrm{~L}^{-1} \mathrm{H}_{2} \mathrm{PtCl}_{6}$-EG solution was dropped into the suspension with urgent agitation for $3 \mathrm{~h}$. The $\mathrm{pH}$ value of the suspension was adjusted to 12 by using a $1 \mathrm{~mol} \mathrm{~L}^{-1} \mathrm{NaOH}-$ EG solution, and the suspension was placed in a microwave oven (Galanz Ltd., $800 \mathrm{~W}$ ) for consecutive heating for $55 \mathrm{~s}$ under flowing Ar. Then, the solution was cooled to room temperature. The $\mathrm{pH}$ value of the solution was adjusted to 3 by dropping $\mathrm{HNO}_{3}$ aqueous solution, which was stirred for $12 \mathrm{~h}$. Finally, the product was washed repeatedly with $80^{\circ} \mathrm{C}$ deionized water. The homemade $\mathrm{Pt} / \mathrm{C}$ catalyst was dried at $80^{\circ} \mathrm{C}$ for $5 \mathrm{~h}$ in a vacuum oven. $\mathrm{Pt} / \mathrm{CeO}_{2}-\mathrm{C}$ catalyst and $\mathrm{PtRu} / \mathrm{C}$ catalyst synthetic process was similar to the above $\mathrm{Pt} / \mathrm{C}$ preparation.

2.2. MEA Fabrication. All MEAs were fabricated by method as previously reported our team [28]. Geometric area of the MEAs was $5 \mathrm{~cm}^{2}$. Homemade $\mathrm{PtRu} / \mathrm{C}$ catalyst was used as anode catalyst, and the metal loading was $2.5 \mathrm{mg} \mathrm{cm}^{-2}$. The schematic diagram of DMFC with double-layered catalyst cathode was shown in Figure 1. The catalyst layer is made up of the inner layer and the outer layer. Homemade $\mathrm{Pt} / \mathrm{C}$ was used as cathode outer layer with metal loading of $2 \mathrm{mg} \mathrm{cm}^{-2}$, and the homemade $\mathrm{Pt} / \mathrm{CeO}_{2}-\mathrm{C}$ was used as cathode inner layer with metal loading of $0.5 \mathrm{mg} \mathrm{cm}^{-2}$. The uniform catalyst ink was made from the mixture of the catalyst, $5 \mathrm{wt}$.\% Nafion ionomer solution (DuPont), water, and isopropyl alcohol, and stirred in an ultrasonic bath continuously at $25^{\circ} \mathrm{C}$. The Nafion content was $20 \mathrm{wt} . \%$. Then, the catalyst ink was brushed onto the gas diffusion layer which was previously prepared by applying microporous layer to the teflonized carbon paper (Toray paper TGPH 090) [29]. Nafion 117 membrane (DuPont) was used as the solid electrolyte. Prior to MEAs fabrication, the pretreatment of Nafion 117 was 
accomplished and treated in 3 wt. $\% \mathrm{H}_{2} \mathrm{O}_{2}$ solution, distilled water, $0.5 \mathrm{~mol} \mathrm{~L}^{-1} \mathrm{H}_{2} \mathrm{SO}_{4}$ solution, and then distilled water again, at $80^{\circ} \mathrm{C}$ for $1 \mathrm{~h}$ each step. MEAs were fabricated by hotpressing anode electrode and cathode electrode on either side of Nafion 117 membrane at $135^{\circ} \mathrm{C}, 100 \mathrm{~kg} \mathrm{~cm}^{-2}$ for $90 \mathrm{~s}$. The preparation of conventional MEA was similar to the MEA with cathode double catalyst layers.

\subsection{Electrochemical and Characterization Techniques. MEAs} were placed in a serpentine flow fields between two graphite plates. Methanol solution $\left(1.5 \mathrm{~mol} \mathrm{~L}^{-1}\right)$ was supplied to anode at flow rates of $3 \mathrm{~mL} \mathrm{~min}^{-1}$, and nonhumidified $\mathrm{O}_{2}$ (ambient pressure) was supplied to cathode at flow rates of $200 \mathrm{~mL} \mathrm{~min}^{-1}$. DMFCs were operated at $80^{\circ} \mathrm{C}$. The single cell performance tests were performed by fuel cell system (Scribner Associates Inc., Series 890e). The polarization and power density curves of MEA were recorded by measuring the current density with voltage gradual reduction from the open circuit voltage to $0.1 \mathrm{~V}$ at an interval scale of $10 \mathrm{mV}$. At each cell voltage, the current density was measured after keeping $3 \mathrm{~min}$ in order to the cell approaching steadystate. The potential-time curves were measured in a constant current mode with current density of $150 \mathrm{~mA} \mathrm{~cm}^{-2}$ for $20 \mathrm{~h}$. Electrochemical impedance spectra (EIS) and linear sweep voltammetry (LSV) were carried out by using a $\mathrm{CHI} 650 \mathrm{E}$ electrochemical analysis to investigate the cell performance at $25^{\circ} \mathrm{C}$. EIS of the MEAs were carried out at $400 \mathrm{mV}$ with amplitude of $5 \mathrm{mV}$ and the frequency from 0.01 to $10 \mathrm{kHz}$. LSV was performed to analyze the quantity of permeated methanol. The cathode and the anode were served as working electrode (WE) and a dynamic hydrogen electrode (DHE), respectively. Methanol solution and humidified nitrogen gas were supplied to anode and cathode side, respectively. Meanwhile, the positive potential was applied to WE from 0.2 to $0.9 \mathrm{~V}$ (versus DHE) with a scan rate of $1 \mathrm{mV} \mathrm{s}^{-1}$.

$\mathrm{X}$-ray diffraction (XRD) pattern of the catalyst was obtained with a $\mathrm{D} /$ max-rB (Japan) diffractometer using a $\mathrm{Cu}$ $\mathrm{K} \alpha \mathrm{X}$-ray source, at a scan rate of $4^{\circ} \mathrm{min}^{-1}$, with scanning range of $10^{\circ}$ to $90^{\circ}$. Morphology and particle size of the catalyst were performed on transmission electron microscopy (TEM, Japan JEOLJEM-2010EX) with an acceleration voltage of $300 \mathrm{kV}$.

\section{Results and Discussion}

The structure and morphology of the as-prepared $\mathrm{CeO}_{2}$ and $\mathrm{Pt} / \mathrm{CeO}_{2}-\mathrm{C}$ hybrids are investigated by means of XRD, TEM, and high-resolution TEM (HRTEM) as shown in Figure 2. XRD patterns of both catalysts show the characteristic (111), (200), (220), and (311) reflections of face centered cubic crystalline Pt and the characteristic (111), (200), (220), (311), (331), and (420) peaks of the cubic fluorite $\mathrm{CeO}_{2}$ (Figure 2(a)). TEM images reveal that the as-synthesized $\mathrm{CeO}_{2}$ possesses a highly dispersed square shape with an average size of about $10 \mathrm{~nm}$ (Figure 2(b)). In Figure 2(c), the crystal plane distances of $0.31 \mathrm{~nm}$ obtained for the $\mathrm{CeO}_{2}$ (111) plane agree very well with the known crystal plane distance, which further confirms the formation of the cubic fluorite structured $\mathrm{CeO}_{2}$. Figures 3(a)-3(d) are TEM images and particle size distribution histogram of $\mathrm{Pt} / \mathrm{CeO}_{2}-$ $\mathrm{C}$ catalyst and $\mathrm{Pt} / \mathrm{C}$ catalyst, respectively. The average crystal sizes of $\mathrm{Pt}$ particles for $\mathrm{Pt} / \mathrm{CeO}_{2}-\mathrm{C}$ catalyst and $\mathrm{Pt} / \mathrm{C}$ catalyst are about 2.3 and $2.6 \mathrm{~nm}$, respectively. Pt nanoparticles are uniformly dispersed on $\mathrm{CeO}_{2}$, indicating that $\mathrm{CeO}_{2}$ can promote the particles dispersion.

Since the MEA with double-layered catalyst cathode has high $\mathrm{CeO}_{2}$ loading on the cathode, the performance is influenced easily by the electrical conductivity and methanol crossover because the $\mathrm{Pt} / \mathrm{CeO}_{2}$-C inner cathode catalyst layer with high $\mathrm{CeO}_{2}$ loading was able to increase charge transfer resistance and the effect of mixed potential. Before the durability investigation of the MEA with double-layered catalyst cathode, the polarization and power density curves of two MEAs are illustrated in Figure 4(a). The MEA with doublelayered catalyst cathode shows a slightly lower performance in comparison with conventional MEA. The polarization curve reveals that the open circuit voltage of the MEA with double-layered catalyst cathode decreases from 0.667 to $0.653 \mathrm{~V}$, and the power density curve shows that the maximum power density is degraded from 118.2 to $86.9 \mathrm{~mW} \mathrm{~cm}^{-2}$. These results can be attributed to the negative shift of onset potential for methanol electrooxidation on $\mathrm{Pt} / \mathrm{CeO}_{2}-\mathrm{C}$ inner catalyst layer and the relatively low electrical conductivity of $\mathrm{CeO}_{2}$. Therefore, the effect of mixed potential is increased and open circuit voltage of DMFC is degraded. Additionally, the addition of $30 \mathrm{wt} . \%$ of $\mathrm{CeO}_{2}$ to catalyst support increases the catalyst layer's resistance a little bit. Thus, the maximum power density of DMFC with double-layered catalyst cathode is slightly lower than that of the conventional MEA.

The methanol electrooxidation currents of MEA with double-layered catalyst cathode and conventional one are carried out by LSV to estimate the resistance of the cathode for permeated methanol, and the LSV curves are shown in Figure 4(b). At low cathode potential region, the onset potential for methanol electrooxidation at $\mathrm{Pt} / \mathrm{CeO}_{2}-\mathrm{C}$ inner cathode catalyst layer is more negative in comparison with single $\mathrm{Pt} / \mathrm{C}$ cathode catalyst layer. At high cathode potential region, methanol electrooxidation reaction is not restricted by the catalytic activity of the electrode, but dominated by methanol permeation rate. The limiting current density of double-layered catalyst cathode is about $67.66 \mathrm{~mA} \mathrm{~cm}^{-2}$, which exhibits relatively higher in comparison with the conventional cathode (around $60.9 \mathrm{~mA} \mathrm{~cm}^{-2}$ ). The results reveal that the addition of $\mathrm{Pt} / \mathrm{CeO}_{2}-\mathrm{C}$ to inner cathode catalyst layer increases the mixed potential at cathode and degrades DMFC power slightly.

To find out the effect of $\mathrm{Pt} / \mathrm{CeO}_{2}-\mathrm{C}$ inner cathode catalyst layer more exactly on DMFC performance, EIS of the MEAs with double-layered catalyst cathode and the conventional one are measured at $25^{\circ} \mathrm{C}$ and DMFC voltage is set at $400 \mathrm{mV}$. Nyquist diagrams and equivalent circuit diagram of MEAs are listed in Figure 4(c). At the whole frequency, the first arc and second arc are ascribed to the charge transfer resistance and diffusion resistance, respectively. At lower frequency, the inductive loop of the fourth quadrant should be the so-called "pseudoinductive" behavior owing to a higher $\mathrm{CO}$ poisoning 


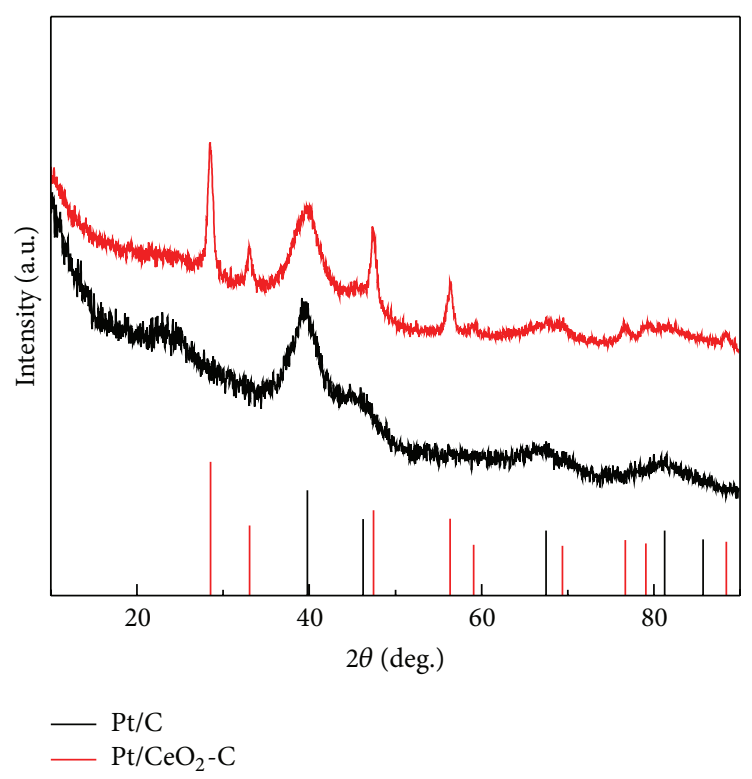

(a)

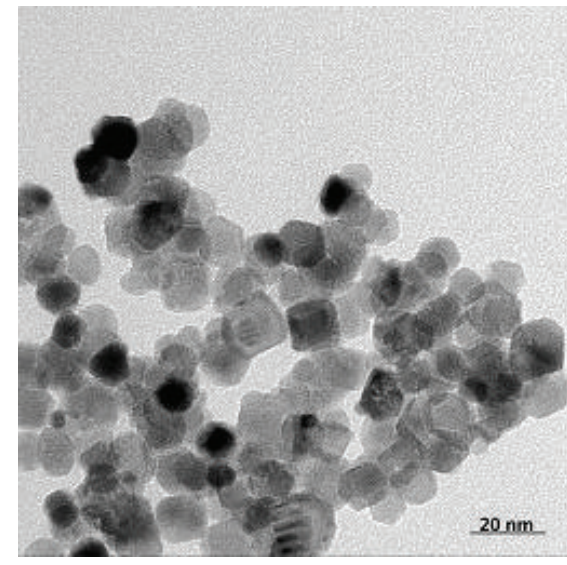

(b)

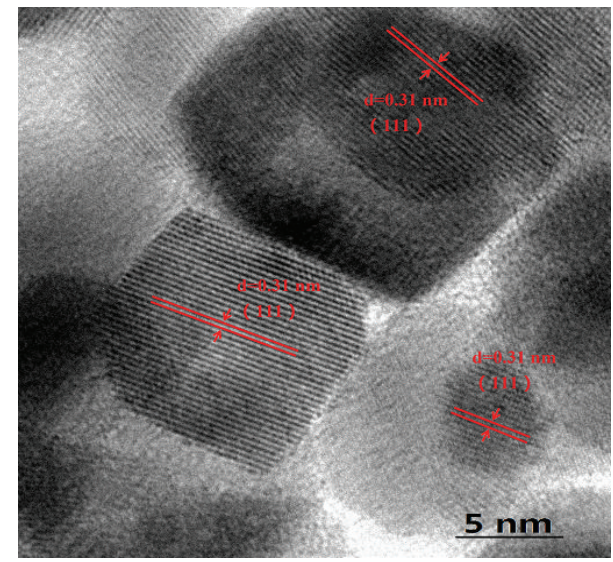

(c)

Figure 2: (a) XRD patterns of Pt/C catalyst (black line) and $\mathrm{Pt} / \mathrm{CeO}_{2}-\mathrm{C}$ catalyst (red line); (b) TEM image for $\mathrm{CeO} \mathrm{O}_{2}$ particles; (c) HRTEM image for $\mathrm{CeO}_{2}$ particles.

$[29,30]$. According to the related value for the different common elements composing obtained by fitting the EIS data, the $R_{\text {Cct }}$ for MEA with double-layered catalyst cathode and conventional MEA is $0.68 \Omega$ and $0.55 \Omega$, respectively. The value of Warburg coefficient for MEA with doublelayered catalyst cathode $\left(28.9 \mathrm{~S} \mathrm{~s}^{0.5}\right)$ is lower than that of conventional MEA $\left(30.7 \mathrm{~S} \mathrm{~s}^{0.5}\right)$. The resistance values of other common elements are similar for both MEAs. The results for equivalent circuit fitting EIS indicate that the MEA with double-layered catalyst cathode exhibits slightly higher charge transfer resistance and diffusion resistance than the conventional MEA without any changes in ohmic resistance. This means that the electrochemical reaction of the MEA with double-layered catalyst cathode is slower than that of the conventional one and its mass transfer resistance is relatively higher. EIS results agree well with those of the polarization curves.
Durability behavior was performed in constant current density of $150 \mathrm{~mA} \mathrm{~cm}^{-2}$ for $20 \mathrm{~h}$ in order to compare the stability of MEAs with double-layered catalyst cathode and the conventional one. The voltage-time curves are shown in Figure 5. The MEA with double-layered catalyst cathode shows significant improvement over the stability of conventional MEA. The degradation rate for MEA with doublelayered catalyst cathode and the conventional cathode is 0.83 and $1.8 \mathrm{mV} \mathrm{h}^{-1}$, respectively. The improvement of MEA stability can be ascribed to the scavenging of free-radicals which would have chemically attacked the membrane and compromised its durability. During the process of free-radical scavenging, the reaction between surface $\mathrm{Ce}^{3+}$ and freeradical, its equation is listed by the following reaction [20, 31]:

$$
\mathrm{HO}^{\bullet}+\mathrm{Ce}^{3+}+\mathrm{H}^{+} \longrightarrow \mathrm{Ce}^{4+}+\mathrm{H}_{2} \mathrm{O}
$$




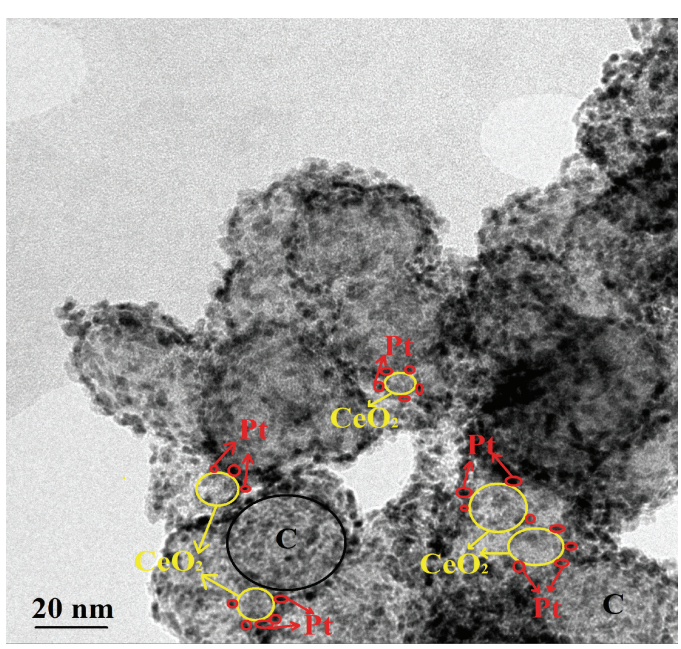

(a)

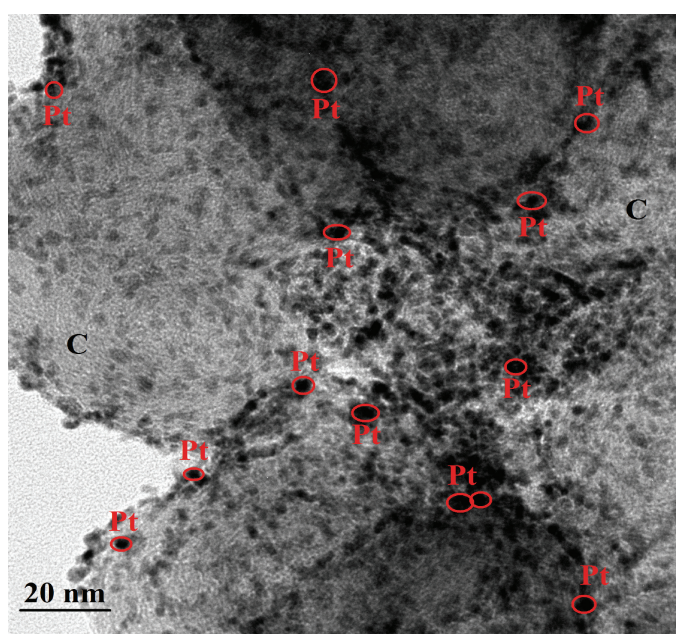

(c)

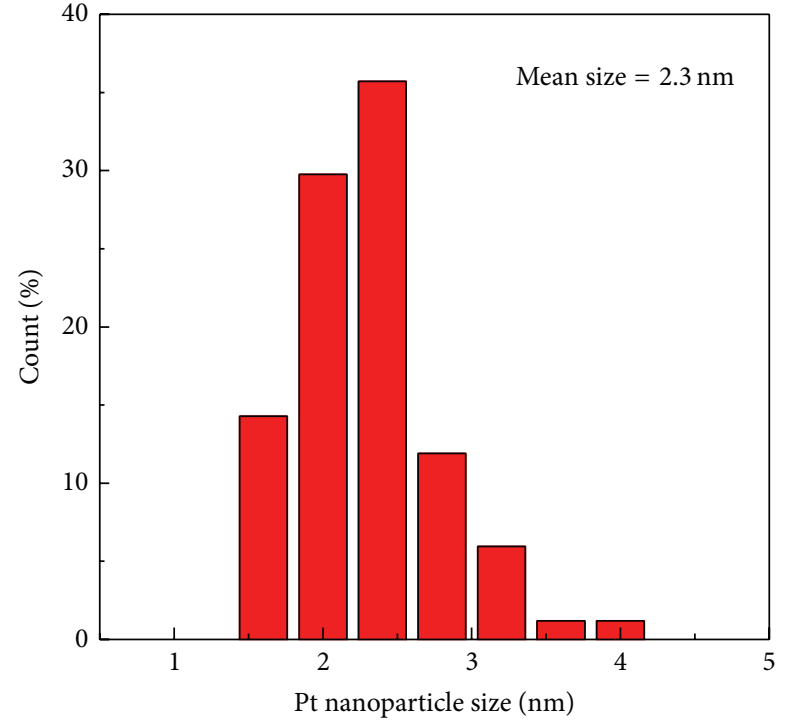

(b)

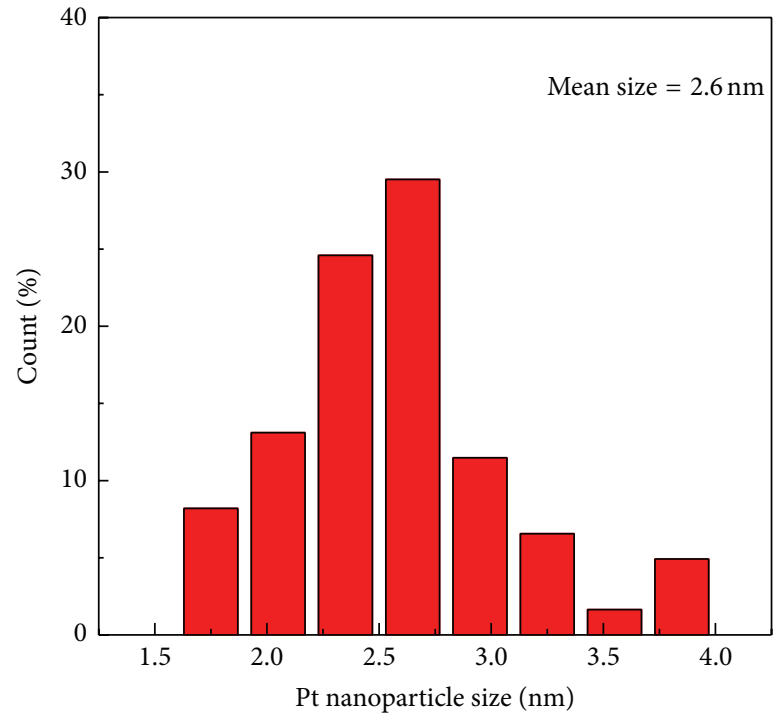

(d)

Figure 3: (a) TEM image for Pt nanoparticles in $\mathrm{Pt} / \mathrm{CeO}_{2}-\mathrm{C}$ catalyst and (b) $\mathrm{Pt} / \mathrm{C}$ catalyst. (c) Particle size distribution histogram of $\mathrm{Pt} / \mathrm{CeO}_{2}$ $\mathrm{C}$ catalyst and (d) Pt/C catalyst.

In $\mathrm{CeO}_{2}$ regeneration process, surface $\mathrm{Ce}^{4+}$ is reduced back to $\mathrm{Ce}^{3+}$ on $\mathrm{CeO}_{2}$ surface as follows:

$$
\begin{aligned}
\mathrm{Ce}^{4+}+\mathrm{H}_{2} \mathrm{O}_{2} & \longrightarrow \mathrm{Ce}^{3+}+\mathrm{HOO}^{\bullet}+\mathrm{H}^{+} \\
\mathrm{Ce}^{4+}+\mathrm{HOO}^{\cdot} & \longrightarrow \mathrm{Ce}^{3+}+\mathrm{O}_{2}+\mathrm{H}^{+} \\
2 \mathrm{Ce}^{4+}+\mathrm{H}_{2} & \longrightarrow 2 \mathrm{Ce}^{3+}+2 \mathrm{H}^{+} \\
4 \mathrm{Ce}^{4+}+2 \mathrm{H}_{2} \mathrm{O} & \longrightarrow 4 \mathrm{Ce}^{3+}+4 \mathrm{H}^{+}+\mathrm{O}_{2}
\end{aligned}
$$

The continuous reaction between multivalent cerium ion and free-radical, especially in acidic conditions, improves regenerative nature of $\mathrm{CeO}_{2}$. Therefore, $\mathrm{CeO}_{2}$ can continually react with free-radicals to protect Nafion from attack, resulting in improved durability of MEA.

\section{Conclusions}

In this study, a double-layered catalyst cathode electrode, consisting of $\mathrm{Pt} / \mathrm{CeO}_{2}-\mathrm{C}$ as inner catalyst and $\mathrm{Pt} / \mathrm{C}$ as outer catalyst, was developed to extend the lifetime and minimize the performance loss of the MEA. The maximum power density of MEA with double-layered catalyst cathode was $87.9 \mathrm{~mW} \mathrm{~cm}^{-2}$, which exhibited slightly lower than that of the conventional one $\left(117.4 \mathrm{~mW} \mathrm{~cm}^{-2}\right)$. MEA with doublelayered catalyst cathode exhibited a low degradation rate of 


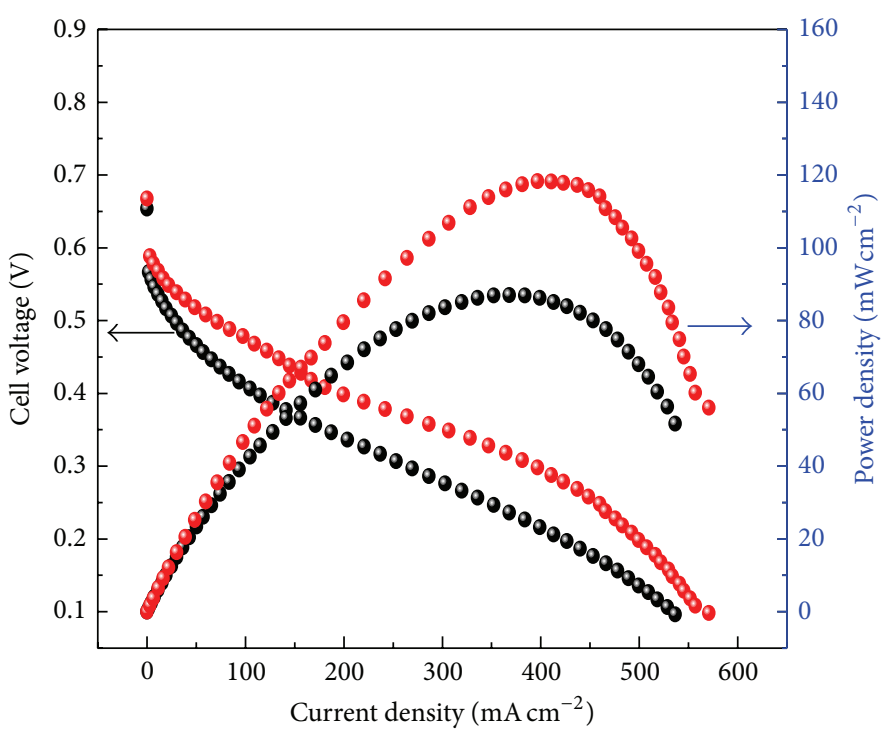

- Double-layered catalyst cathode - Conventional catalyst cathode

(a)

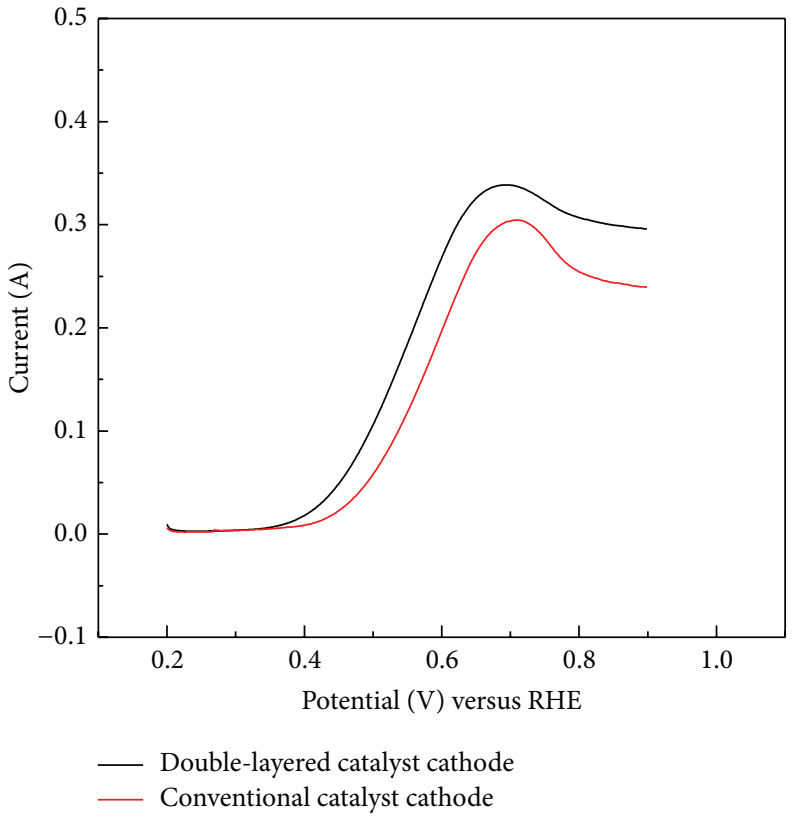

(b)

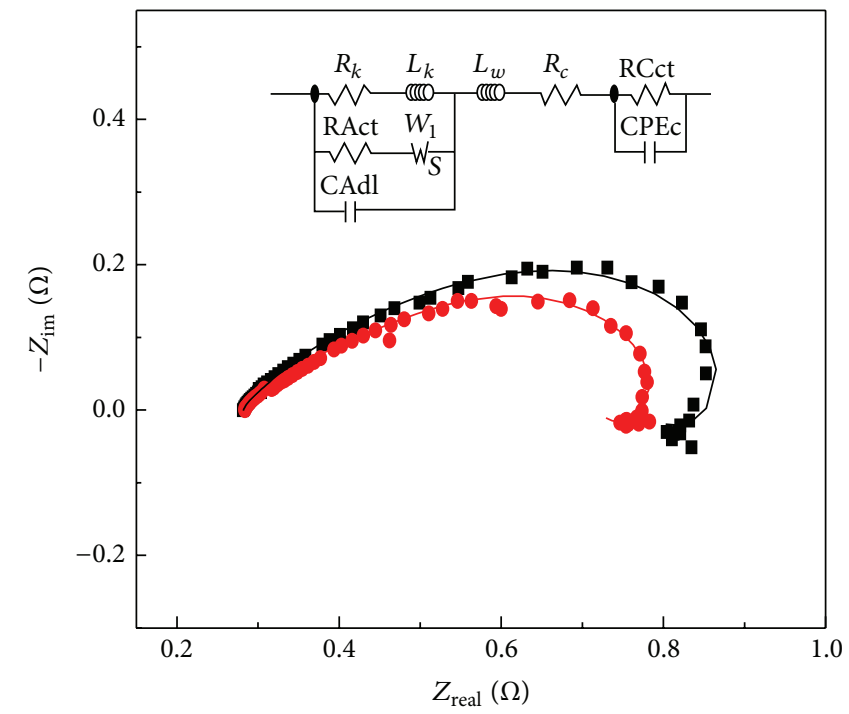

- Double-layered catalyst cathode

- Conventional catalyst cathode

(c)

FIgURE 4: (a) Performance of MEA with double-layered and conventional catalyst cathode. Temperature: $80^{\circ} \mathrm{C} . \mathrm{Anode} \mathrm{feed:} 2 \mathrm{~mol} \mathrm{~L}^{-1} \mathrm{CH} \mathrm{OH}^{\mathrm{O}}$ solution. Flow rate: $3.0 \mathrm{~mL} \mathrm{~min}{ }^{-1}$. Cathode feed: oxygen at ambient pressure. Flow rate: $200 \mathrm{~mL} \mathrm{~min}^{-1}$. (b) Linear sweep voltammograms of methanol permeating through the membranes at the double-layered catalyst and the conventional cathode. (c) Nyquist diagrams of MEA with double-layered catalyst and the conventional cathode at $400 \mathrm{mV}$; the lines correspond to the fit by the equivalent circuit. Anode feed: $2 \mathrm{~mol} \mathrm{~L}^{-1} \mathrm{CH}_{3} \mathrm{OH}$ solution. Flow rate: $3.0 \mathrm{~mL} \mathrm{~min}^{-1}$. Cathode feed: oxygen at ambient pressure. Flow rate: $200 \mathrm{~mL} \mathrm{~min}^{-1}$. 


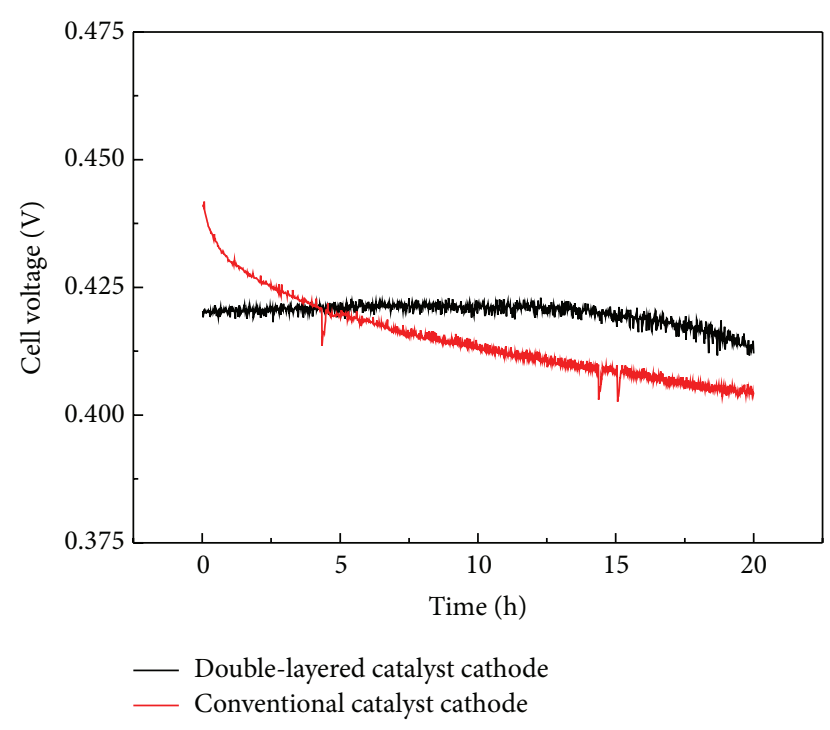

Figure 5: Voltage-time curves of the MEA with double-layered and conventional catalyst cathode continuously operated for $20 \mathrm{~h}$ at a constant current density of $150 \mathrm{~mA} \mathrm{~cm}^{-2}$.

$0.83 \mathrm{mV} \mathrm{h}^{-1}$, which was around $55 \%$ lower than the conventional MEA. Pt/ $\mathrm{CeO}_{2}-\mathrm{C}$ as free-radical scavengers into inner cathode catalyst layer greatly improved the stability of MEA, although they slightly increased the effect of mixed potential. The improvement of stability can be attributed to the ability of $\mathrm{CeO}_{2}$ to act as free-radical scavengers.

\section{Conflict of Interests}

The authors declare that there is no conflict of interests regarding the publication of this paper.

\section{Acknowledgments}

This research is financially supported by the National Natural Science Foundation of China (Grant no. 21273058), China Postdoctoral Science Foundation (Grant nos. 2012M520731 and 2014T70350), Heilongjiang Postdoctoral Foundation (LBH-Z12089 and LBH-Z11038), the Natural Science Foundation of Heilongjiang Province of China (Grant no. B201203), and the Fund of Department of Education of Heilongjiang Province of China (Grant no. 12521427).

\section{References}

[1] S. Sharma and B. G. Pollet, "Support materials for PEMFC and DMFC electrocatalysts-a review," Journal of Power Sources, vol. 208, pp. 96-119, 2012.

[2] S. Basri, S. K. Kamarudin, W. R. W. Daud, and Z. Yaakub, "Nanocatalyst for direct methanol fuel cell (DMFC)," International Journal of Hydrogen Energy, vol. 35, no. 15, pp. 7957-7970, 2010.

[3] E. Antolini, T. Lopes, and E. R. Gonzalez, "An overview of platinum-based catalysts as methanol-resistant oxygen reduction materials for direct methanol fuel cells," Journal of Alloys and Compounds, vol. 461, no. 1-2, pp. 253-262, 2008.
[4] X. Zhao, M. Yin, L. Ma et al., "Recent advances in catalysts for direct methanol fuel cells," Energy and Environmental Science, vol. 4, no. 8, pp. 2736-2753, 2011.

[5] V. Neburchilov, J. Martin, H. Wang, and J. Zhang, "A review of polymer electrolyte membranes for direct methanol fuel cells," Journal of Power Sources, vol. 169, no. 2, pp. 221-238, 2007.

[6] A. Mehmood, M. G. An, and H. Y. Ha, "Physical degradation of cathode catalyst layer: a major contributor to accelerated water flooding in long-term operation of DMFCs," Applied Energy, vol. 129, pp. 346-353, 2014.

[7] J.-H. Kim, M.-J. Yang, and J.-Y. Park, "Improvement on performance and efficiency of direct methanol fuel cells using hydrocarbon-based membrane electrode assembly," Applied Energy, vol. 115, pp. 95-102, 2014.

[8] C. C. Ke, X. J. Li, S. G. Qu, Z. G. Shao, and B. L. Yi, "Preparation and properties of Nafion $/ \mathrm{SiO}_{2}$ composite membrane derived via in situ sol-gel reaction: size controlling and size effects of $\mathrm{SiO}_{2}$ nano-particles," Polymers for Advanced Technologies, vol. 23, no. 1, pp. 92-98, 2012.

[9] Y.-C. Park, D.-H. Kim, S. Lim, S.-K. Kim, D.-H. Peck, and D.-H. Jung, "Design of a MEA with multi-layer electrodes for high concentration methanol DMFCs," International Journal of Hydrogen Energy, vol. 37, no. 5, pp. 4717-4727, 2012.

[10] S. Rousseau, C. Coutanceau, C. Lamy, and J.-M. Léger, "Direct ethanol fuel cell (DEFC): electrical performances and reaction products distribution under operating conditions with different platinum-based anodes," Journal of Power Sources, vol. 158, no. 1, pp. 18-24, 2006.

[11] A. Kianimanesh, Q. Yang, S. S. Park, D. Xue, and T. Freiheit, "Model for the degradation performance of a single-cell direct methanol fuel cell under varying operational conditions," Fuel Cells, vol. 13, no. 6, pp. 1005-1017, 2013.

[12] M. K. Debe, "Electrocatalyst approaches and challenges for automotive fuel cells," Nature, vol. 486, no. 7401, pp. 43-51, 2012.

[13] L. Wang, S. G. Advani, and A. K. Prasad, "Degradation reduction of polymer electrolyte membranes using $\mathrm{CeO}_{2}$ as a freeradical scavenger in catalyst layer," Electrochimica Acta, vol. 109, pp. 775-780, 2013.

[14] Z. Wang, H. Tang, H. Zhang et al., "Synthesis of Nafion/CeO hybrid for chemically durable proton exchange membrane of fuel cell," Journal of Membrane Science, vol. 421-422, pp. 201-210, 2012.

[15] V. Prabhakaran, C. G. Arges, and V. Ramani, "Investigation of polymer electrolyte membrane chemical degradation and degradation mitigation using in situ fluorescence spectroscopy," Proceedings of the National Academy of Sciences of the United States of America, vol. 109, no. 4, pp. 1029-1034, 2012.

[16] H. Hori, M. Murayama, T. Sano, and S. Kutsuna, "Decomposition of perfluorinated ion-exchange membrane to fluoride ions using zerovalent metals in subcritical water," Industrial \& Engineering Chemistry Research, vol. 49, no. 2, pp. 464-471, 2010.

[17] P. X. Huang, F. Wu, B. L. Zhu et al., " $\mathrm{CeO}_{2}$ nanorods and gold nanocrystals supported on $\mathrm{CeO}_{2}$ nanorods as catalyst," The Journal of Physical Chemistry B, vol. 109, no. 41, pp. 19169-19174, 2005.

[18] S. Babu, A. Velez, K. Wozniak, J. Szydlowska, and S. Seal, "Electron paramagnetic study on radical scavenging properties of ceria nanoparticles," Chemical Physics Letters, vol. 442, no. 4-6, pp. 405-408, 2007. 
[19] D. Schubert, R. Dargusch, J. Raitano, and S.-W. Chan, "Cerium and yttrium oxide nanoparticles are neuroprotective," Biochemical and Biophysical Research Communications, vol. 342, no. 1, pp. 86-91, 2006.

[20] P. Trogadas, J. Parrondo, and V. Ramani, “ $\mathrm{CeO}_{2}$ surface oxygen vacancy concentration governs in situ free radical scavenging efficacy in polymer electrolytes," ACS Applied Materials and Interfaces, vol. 4, no. 10, pp. 5098-5102, 2012.

[21] S. Xiao, H. Zhang, C. Bi et al., "Membrane degradation mitigation using zirconia as a hydrogen peroxide decomposition catalyst," Journal of Power Sources, vol. 195, no. 24, pp. 80008005, 2010.

[22] Y. Li, W. Chen, Q. Xu, J. Zhou, Y. Wang, and H. Sun, "Piezoelectric and dielectric properties of $\mathrm{CeO}_{2}$ doped $\mathrm{Bi}_{0.5} \mathrm{Na}_{0.44} \mathrm{~K}_{0.06} \mathrm{TiO}_{3}$ lead-free ceramics," Ceramics International, vol. 33, pp. 95-99, 2007.

[23] L. Wang, S. G. Advani, and A. K. Prasad, "Self-hydrating $\mathrm{Pt} / \mathrm{CeO}_{2}$-nafion composite membrane for improved durability and performance," ECS Electrochemistry Letters, vol. 3, no. 5, pp. F30-F32, 2014.

[24] A. M. Baker, L. Wang, W. B. Johnson, A. K. Prasad, and S. G. Advani, "Nafion membranes reinforced with ceria-coated multiwall carbon nanotubes for improved mechanical and chemical durability in polymer electrolyte membrane fuel cells," Journal of Physical Chemistry C, vol. 118, no. 46, pp. 2679626802, 2014.

[25] J. Parrondo, P. Trogadas, and V. Ramani, "Degradation mitigation in polymer electrolyte membranes using free radical scavengers," ECS Transactions, vol. 16, no. 2, pp. 1725-1733, 2008.

[26] Y. Gu, C. Liu, Y. Li, X. Sui, K. Wang, and Z. Wang, " $\mathrm{Ce}_{0.8} \mathrm{Sn}_{0.2} \mathrm{O}_{2-\delta}-\mathrm{C}$ composite as a co-catalytic support for $\mathrm{Pt}$ catalysts toward methanol electrooxidation," Journal of Power Sources, vol. 265, pp. 335-344, 2014.

[27] D. M. Gu, Y. Y. Chu, Z. B. Wang, Z. Z. Jiang, G. P. Yin, and Y. Liu, "Methanol oxidation on $\mathrm{Pt} / \mathrm{CeO}_{2}-\mathrm{C}$ electrocatalyst prepared by microwave-assisted ethylene glycol process," Applied Catalysis B: Environmental, vol. 102, no. 1-2, pp. 9-18, 2011.

[28] Z.-B. Wang, P.-J. Zuo, Y.-Y. Chu, Y.-Y. Shao, and G.-P. Yin, "Durability studies on performance degradation of $\mathrm{Pt} / \mathrm{C}$ catalysts of proton exchange membrane fuel cell," International Journal of Hydrogen Energy, vol. 34, no. 10, pp. 4387-4394, 2009.

[29] L.-H. Xing, G.-P. Yin, Z.-B. Wang, S. Zhang, Y.-Z. Gao, and C.Y. Du, "Investigation on the durability of direct dimethyl ether fuel cell. Part I: anode degradation," Journal of Power Sources, vol. 198, pp. 170-175, 2012.

[30] Z.-B. Wang, C.-R. Zhao, P.-F. Shi et al., "Effect of a carbon support containing large mesopores on the performance of a $\mathrm{Pt}-\mathrm{Ru}-\mathrm{Ni} / \mathrm{C}$ catalyst for direct methanol fuel cells," The Journal of Physical Chemistry C, vol. 114, no. 1, pp. 672-677, 2010.

[31] F. D. Coms, H. Liu, and J. E. Owejan, "Mitigation of perfluorosulfonic acid membrane chemical degradation using cerium and manganese ions," ECS Transactions, vol. 16, no. 2, pp. 1735$1747,2008$. 

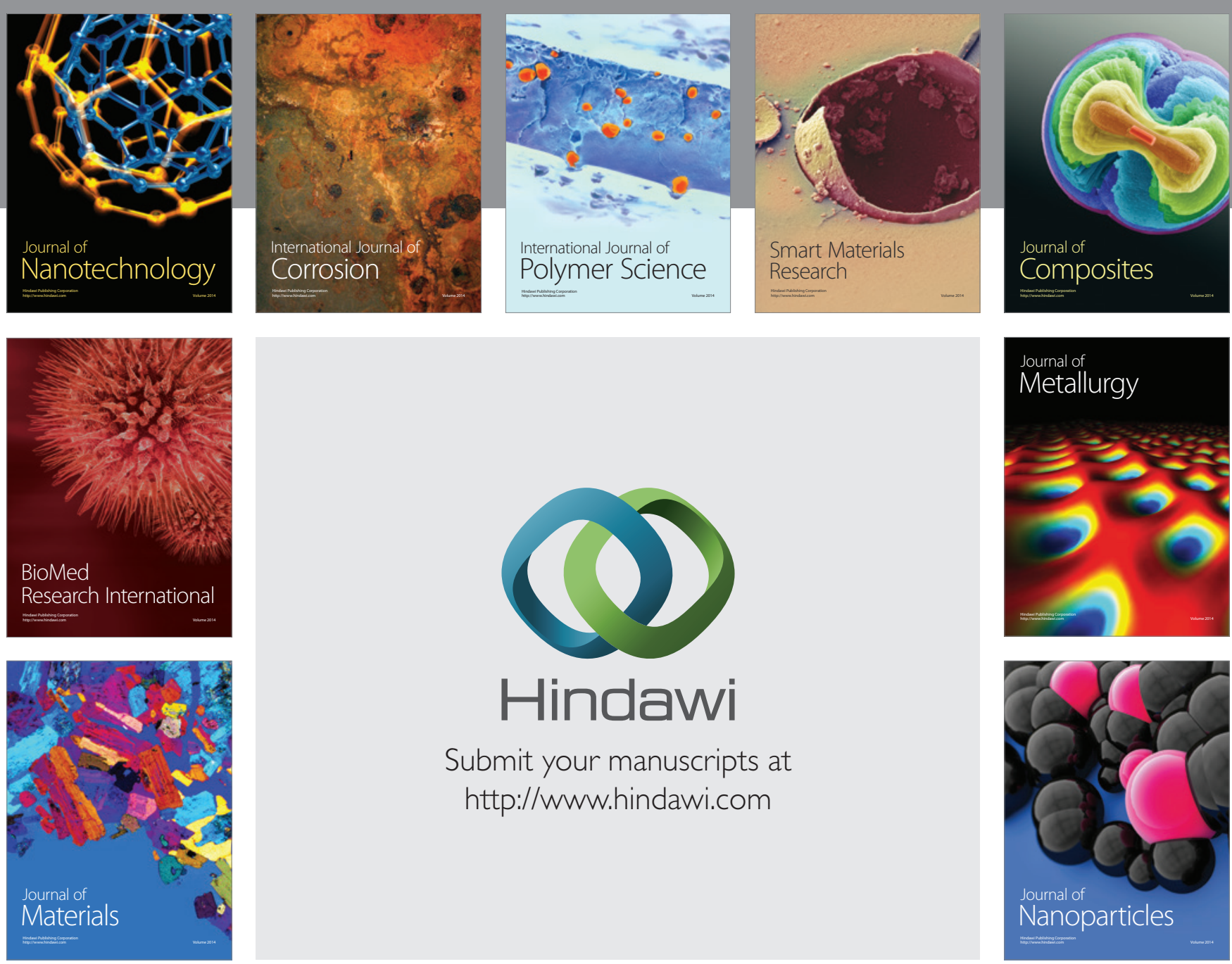

Submit your manuscripts at http://www.hindawi.com
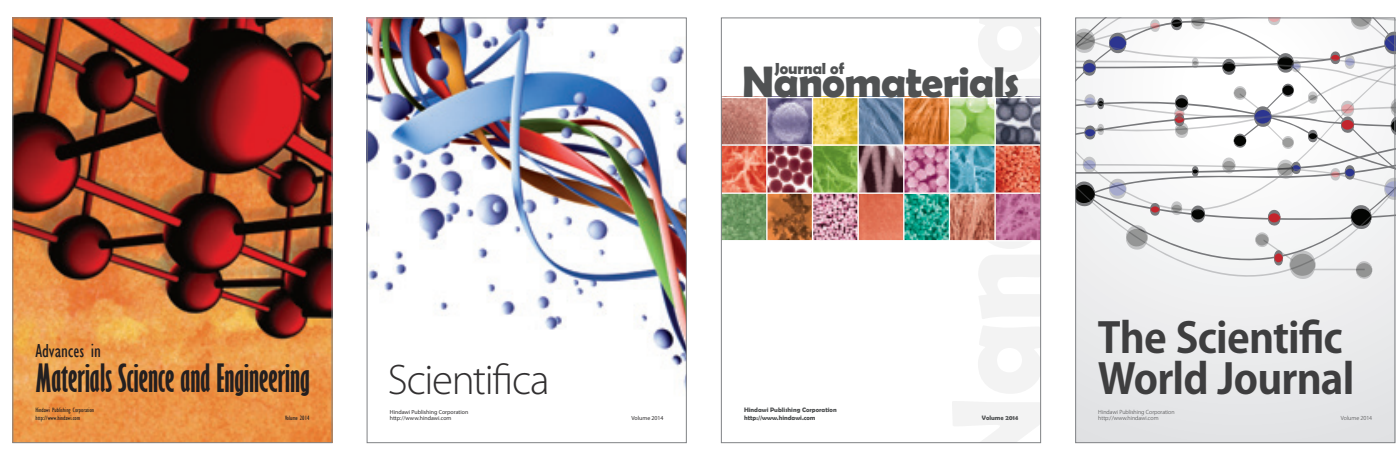

\section{The Scientific World Journal}
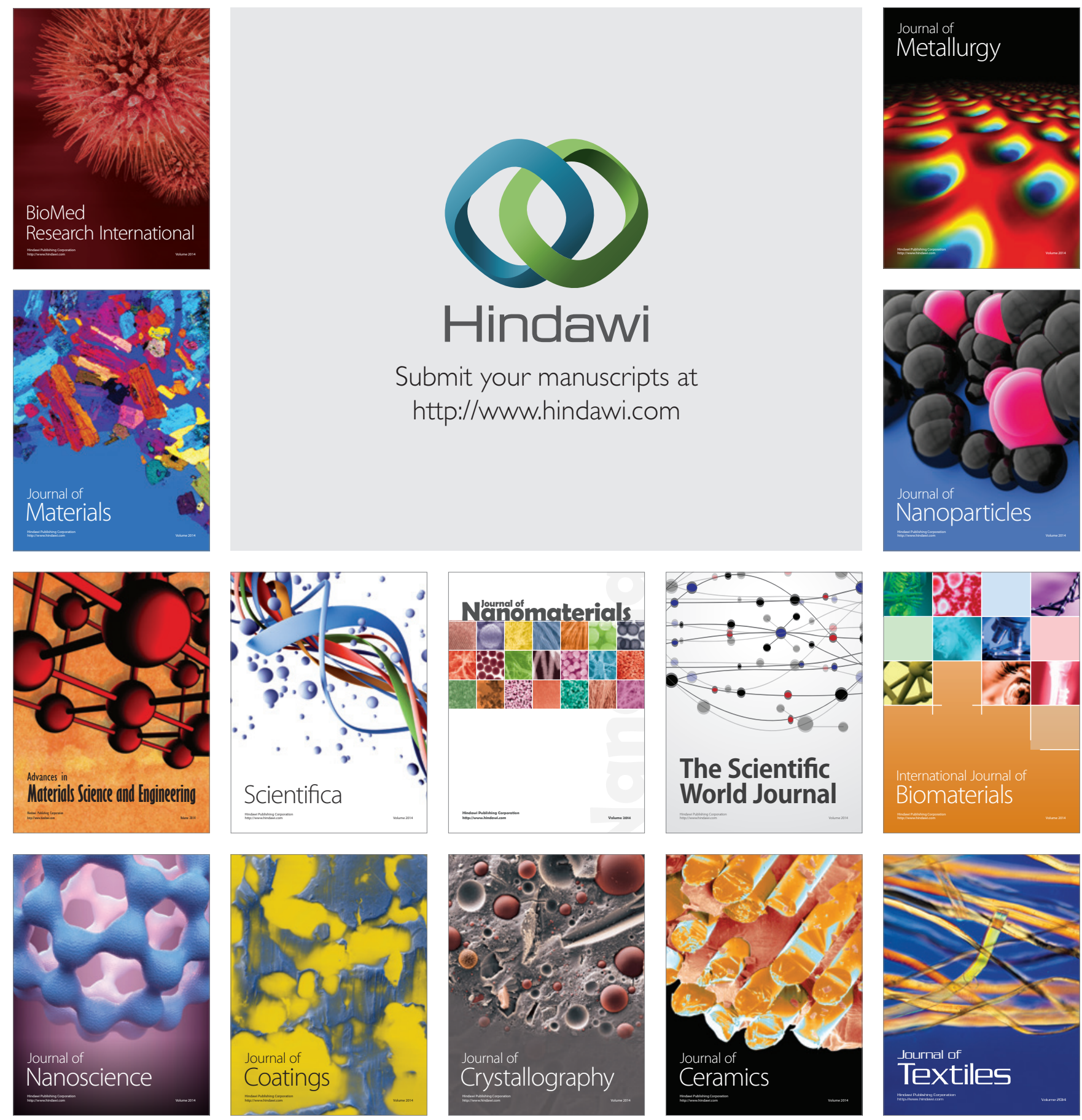